\title{
Historical Analysis of Tense Category in Slavic Languages
}

\author{
Huseynova R.N. \\ Foreign Languages Department \\ Azerbaijan Medical University \\ Baku, AAzerbaijan
}

\begin{abstract}
In our research, the Slavic languages are examined and analyzed by the historical development stages of the tense category and the changes observed during these stages. Lack of unanimous views and considerations in the linguistic literature on the tense category dictates the relevance of the chosen topic. The aim of the study is to study tense categories in Slavic languages in a diachronic manner. Analyzing the materials of the Czech, Bulgarian, Macedonian, Russian and other Slavic languages on the basis of typologicalcomparative and historical comparative methods the author tried to investigate the manifestation forms of this category. Widespread coverage of tense categories in Slavic languages in a diachronic aspect necessitates the scientific novelty of the research. One of the results obtained in the study is that in addition to the tense category, the taxis morphological category is also used to refer to all other Slavic languages except Russian. The results obtained in the study can be used in Slavic languages as an important source for future research on time, verb, temporality, and taxis.
\end{abstract}

Keywords-tense category; diachronic; verb; temporality; taxis; the Czech language; the Bulgarian language.

\section{INTRODUCTION}

Interpretation of the concept of grammatical category in modern linguistics is provided by A.I.Smirnitski [1: 6-10]. He considers that these are common meanings (for example, present, past, future) and systematic confrontation of various forms that have common meanings (e.g., time) at the highest levels which can be defined as the grammatical category of this or another unified language. Thus, the grammatical categories can be referenced by status, person, verb form, grammatical categories in Russian as well as in Slavic languages and several other languages. It follows that the grammatical category refers to a particular material unit. A.I.Smirnitsky showed that: 1) Any grammatical category consists any grammatical category and represents a categorical form; 2) Any grammatical category must have at least two categories of forms (there is no language that exists only one future tense); 3) No category can take part in all grammatical forms of the word; hence, in all Slavic languages, nouns that do not change by gender refer to a particular grammatical gender, which is the gender category in nouns; 4) Different grammatical categories (tense, verb form, aspect, person, quantity) can almost be combined in the same word-form; 5) Two categories of the same category cannot be combined in one word-form.

In Slavic languages, the tense category is younger compared to the aspect category. Time limitations are laid to the aspect conflict. The present, past and future grammatical times are distinguished. In turn they have different meanings. For example, recent past and past meanings of the past tense continued in the present, while the future tense has the meanings of the near and far future.

\section{RESEARCH METHODOLOGY}

The main purpose of the investigation is to study the tense category in Slavic languages. Analyzing Czech, Bulgarian, Macedonian, Russian and other Slavic languages' materials on typological-comparative and historical comparative methods we tried to investigate the manifestation forms of the tense category in these languages. Lack of common ideas and views on tense category in linguistic literature implies the actuality of the chosen topic.

\section{RESULTS}

\section{Present and future in Slavic languages}

The distinction between present and future was initially reflected in the aspect meaning of the verb. If the verb was in the perfect form, its present-day forms would gain a future meaning, f.e. скажу or скажет; if the verb wasn't in the perfect form, its present-day forms did not differ in the sense of time, for example: говорю оr говорит. Completed aspect verbs didn't use in the present, the unfinished aspect verbs could have only a descriptive future (буду говорить).

As time limitation emerged, the ancient aspect category began to form the basis of certain tense constructions. The category of lasting aspect is the basis of the present ( $A$ ноиу) and one of the meanings of the past ( $я$ носил). However, one tense has several aspects, for example, the beginning verbs indicating the beginning of a movement, and the lasting verbs form the basis of the present. At first, the tense is layered to the aspect, and then the new aspect differences widened and complicated the tense limitation system. 
The time category is interrelated with the aspect category. Like all grammatical categories, they have historically been formed. In ancient times, the concept of time is characteristic of concrete localization and it is clear from this point of view that in ancient times the perceptions of time depend on specific aspect categories. In modern Russian language, aspect and tense are interrelated and have the same origin, as the perception of abstract time necessitated abstact aspect perceptions. If we look back at the ancient period, we can see that the category of time was perceived as a local space and determined aspect-time category. Thus in that time that was at this time that the notion of time was associated with the notion of the beginning and end of the action, the action flow. Thus, in the ancient Russian language, the tense category determined the concept of a particular space and depended on the aspect category.

The verb tense category is one of the most important grammatical categories and, like other grammatical categories, has risen to the popular level of abstraction. For the expression of the future tense the future, present (in the meaning of я еду завтра на север; я поеду and as well as the past (in the meaning of пропала твоя головушка; nponadem) is used. Present, past and future tense are grammatically limited, but accessing one area to another is related to the specific conditions of the context. The grammatical notion of time is logically broader than the idea of time. Trom this point of view the present time, in certain cases, generally represents the idea of time. For example, in the sentence Они работают отлично it is obvious that they always work perfectly.

In modern Slavic languages, it is not advisable to use the term perfect for the past forms. First, in most modern Slavic languages' grammar, the term perfect is not used; secondly, in many Slavic languages there is only form of the past (universal preterite), and thirdly, the analytical forms of the past are similar to the ancient Slavic, the ancient Russian perfect. This form is the only form of expression of the past. Thus, in modern Slavic languages, we come across to the model auxiliary verb + -л, analytical forms similar to the ancient Slavonic, the ancient Russian perfect in the western and southern Slavic branch [1].

It should be noted that word forms are edited both analytically and synthetically. For example, in Bulgarian language, uе чета future form and its generative tense form, on the one hand, are united with the synthetic forms (чета, четях, четох), on the other hand, with the tense meaning, as it refers only to the ще чета construction, they are not available in the искам да чета "I want to read", мога dи чета "I can read" constructions. Some grammatists believe that пусть/пускай constuctions enter to verb paradigm as an imperative analytical forms or present or future verb forms in Russian [2, 72].

An upper Luke language are interesting in the past verbs forms' system, the mutuality case and iterative forms are used as grammatical homonyms, Knarodinam by nan małemu jubiłarej stajnje całty z koibasku prinjest "At a child's birthday, the father always brought sausages and cookies to the little boy" [3, 164]. In Polish, the simple forms of the past like krytem, kryteś, kryt are characteristic, so that in the unfinished aspect the future forms of the verbs are formed with the help of -л- form analytically, for example: będę kryt / będę kryć. According to A. Lamprecht, the new perfect like имам работано, имам бегано is always available in the Macedonian language in all tense forms. Although such forms exist in the Czech spoken language, the Slovak and and the Polish language, only these forms are part of the morphological system in Macedonian language [4, 183-184]. In the past, if the speakers in Bulgarian and Macedonian languages are witnesses of the action, they use the aorist, and if they are not witnesses of the action, they use the perfect tense form [4, 182-183]

It should be noted that grammatical time is not always compatible with real time. For this reason, the real future is conditional, the maximum number of grammatical forms for the expression of the future is two, and present tense expresses the actuality, reality, it is not present are not classified on this purpose. In many languages the past tense has more forms (the Bulgarian and Macedonian languages), so logically the past tense can be simple or indefinite. From this perspective, Czech scientist Fr. Chermak's note is of interest: "In Slavic languages, for example, in Bulgarian and Macedonian languages, the tense category is rich, it is expressed in indirect evidence, so that non-insured content is formed (in the senteces beginning with "as if") "( Čermák 1994: 151).

The only form of the past in the Czech language is analytic preterite construction, for example: Jde o form, jež vyjadřuje děj, který se odehrál před okamžikem promluvy [5, 316].

Grammatical present tense form sometimes reflects the general time idea. In certain cases this idea can be attributed to the past and the future. However, the "speech moment" has its meaning in these cases, because the use of tenses is perceived as "special". In the "Они работают отлично" sentence the verb работают is a grammatical form of the present tense.

The tense category relates to the characteristic of the movement or the situation with attitude to a particular time point taken at the end point. In this connection, there are three main time-based definitions of the categorical-time interpretation of reality: the speech moment or the main action - taken as the end point (present), beyond the grammatical consciousness - increasing change (for example, during the dialogue or from one event to another); before (the past) and after (the future) of the "calculation point".

The historical aspect of tense category in Slavic languages

In Slavic languages, the tense category is defined by present, past and future category forms. This is the case in modern Russian. Other Slavic languages are more common these days. In addition to the present, past and future, the Polish language also contains a long and plushkwamperfekt. 
True, it is rarely used in the Polish language, but it does not disappear. The same is true in the Czech language. However, pluskwamperfekt is not used in spoken language, but has been preserved in the book language until the twentieth century (Molochnaya, 43).

In the Serbian-Croatian and Macedonian languages, the tense category contains more members than the paradigm. There is present, past perfect - aorist, past-unfinished imperfect, past indefinite - perfect, distant past, plusquamperfect, I future, II future in Serbo-Croatian language. In the Macedonian language, the forms are: present, past perfect - aorist, past unfinished - imperfect, past indefinite - perfect, preceding past - plusquamperfect, future in the past.

In the ancient Slavic language, the action of the past was expressed in three grammatical times: aorist, imperfect, perfect, plusquamperfect. This system of the past is proved by other monuments in other ancient Slavic languages, for example, in an ancient Russian and ancient Czech languages. This gives rise to the fact that the great Slavic language also has four past forms. In the Indo-European language, the great Slavic language took some forms of aorist. Other grammatical formal means reflect the novelty of the Slavic language.

Contemporary Slavic languages, which have the past, are divided into two groups: a) North Slavic languages. In these languages, the aorist and imperfect disappeared completely, and the plusquamperfect partially disappeared. In the past, the meaning is given in the form corresponding to the perfect. Exceptions are the Lud languages where are the aorist, imperfect, plusquamperfect; b) South Slavic languages. In these languages, the past is represented by a complex tense system. The Slovenian language is an exception in the South Slavic languages, as it has existed only one past tense.

In modern Russian language, as in German and English languages, there are no analytical forms of perfect, so people speaking in Russian have difficulty in understanding the forms of English and German. In this regard, Yu.M. Krivosheyeva compares the Russian-English tense system and notes: "The perfect action is a convenient material to indicate that one event occurred in the past before another. The English-aspect system can be thought of as a chronotypical model. In this model, the relationship of time and space is inextricably united and it is the structure and expression form of cultural experience and consciousness of a nation speaking and thinking through it. From the language experience, it is clear that a single information cannot consist of a perfect, as perfect cannot organize the word meaning. The giving information with perfect forms is the addition to the basis, it separates what is important and makes active one of the components of speech , emphasizing the hidden meaning, background and presumption that the speaker gives in the information "(Krivosheeva 2012: 125-126).

Reconstruction of the historical system of the past in Slavic languages is connected with the solution of many complex issues. What did each of these four past times have in the ancient Slavic, Proto Slavic and separate Slavic languages? What were their systemic relationships in each Slavic language, and why did the North Slavic languages lose their complex past tense system? The solution of these complex issues is also related to the fact that the voice of Slavic language is closely related to the tense category. It is possible to give a brief summary about them, as they have different ideas about each one.

A simple aorist is one of the three aorists having being described in ancient Slavic languages and is based on ancient Indo-European athematic aorist (or imperfect). A simple aorist is no longer an ancient form. It is found in the Gospel of Zograph and Maria, and is virtually absent in later Cyrillic monuments, such as the Suprasl manuscript. Ancient Slavic monuments show that in the 11th century's speech, simple aorist forms were out of order. Simple aorist can be found only once in Suprasl's handwriting.

There are more tense forms in Bulgarian grammar: present, past perfect - aorist, past unfinished - imperfect, past indefinite (simple), distant past - plusquamperfect, future, future in the past, initial future, initial future in the past. Looking at these forms, one can see that the tense category is complex in the Bulgarian language. As we know, grammatical tradition distinguishes between absolute and relative time $[6,85-103 ; 7,49-66]$.

Absolute time is the moment when the action or outcome of the speech is coincided with the integration moment of $\left(A_{1}\right)$. These are the present, the future, the aorist, the perfect and the first future tense forms. They express the action before, following and simultaneity towards speech moment. There is another integration moment in the formation of meaning of verb forms, that is, the concrete moment $\left(A_{2}\right)$, which is defined by other events. For example, imperfect expresses the simultaneity action in the past: Веднъж, докато траеше дъждът, чичо Митуш и Аго седяха на сундурмата пред дама "One day, before the rain, Mithus and his uncle Ago were sitting on the soil ground". In this example, the action is given by the form седяxa with the form mpaeme shows the past simultaneity action. The continuation of the action after integrity moment is not important with its expression in imperfect, since the meaning of the imperfect only covers the past integrity moment or time interval. In other words, the imperfect represents a dual relationship, on the one hand, it is the same as the moment when the action is spoken, and on the other hand, the moment has passed in relation to the speech moment. Thus, if the imperfect is focused on the past integrity moment, the present tense focused on the speech moment. From this point of view I. Kusarov considers the imperfect as relative present tense (Kutsarev Iv. Problems of Bulgaran morphology. Plovdiv, 1993, 66-74).

The future in the past represents the future action in the relation to any past tense. For example, Тежка щеще да бъде жетвата, а при тия високи стьбла на житата още потежка щеще да бъде въриитбата "The harvest was difficult, and it was more difficult to beat the high and thick spikes". In this passage, the щзеще да бъде verb form considers the harvest and the weaving of the grain as the 
future tense towards the speech moment. The speaking past moment is shown with another past form. Then, the future in the past notifies the another following past tense. For example: Две черни горящи очи чакаха да доловят тайната, която щеще да разбули дядо Гено "Two black eyes were trying to uncover the mystery that Qeno grandfather wanted to tell". In this passage, чакаха shows the action taken place in the past, and it indicates the fututre action towards щеще да разбули чакаха. Thus, the future in the past, on the one hand, is the future towards the moment, on the other hand, is the past towards the expression moment, that is, the future in the past integrated to the integrity moment $\left(\mathrm{A}_{2}\right)$ and express the relative time meaning (T.N.Moloshnaya. Grammatical categories of verb in moern Slavic literary languages. M., 2001, p. 96, p.45). It should be noted that the time corresponding to the $\mathrm{A}_{2}$ is called relative. In addition to the imperfect, future in the past plusquamperfect, the first future in the past tense is also refers here.

However, it is well known that the confrontation between the verb forms corresponding to $A_{1}$ and the verb form corresponding to $\mathrm{A}_{2}$ is not a conflict within the category of grammatical time. This is due to another grammatical category called taxis. The term was first used by $\mathrm{R}$. Jacobson and he differs the taxis category from the tense category: "Taxis characterizes the given fact towards the another given information (R.Jacobson. Shifters, verb category and Russian verb//The principles of typological analysis of languages with diferent constructions. M., 1972, 101). Before this term was widely used, A.I.Smirnitski proposed this category to be a grammatical category of tense relativity (A. Smirnitsky. Morphology of English Language. M., 1959, 291). Although R.Jacobson considers taxis as morphological category, A.V.Bondarko refers it to thesyntactic phenomena and treats it as a functionalsemantic field in accordance with its general theory (Bondarko A.V. Temporality // Theory of Functional Grammar. 1990, 13-18). After V.I.Bondarko I. Kusarov also refers taxis following as a functional-semantic field with morphological, syntactic and lexical expressions (Kutsarev Iv.Problems of Bulgarian morphology/ Plovdiv, 1993, 7481).

The attraction of the taxis category to the tense category helps to learn the verb forms of Polish and Czech languages. The form plusquamperfekt is directed to the $A_{2}$, different from the present, past and future. For example: Ale ona odwrocila sie juz do kuferka... I bezmyslnie pzdekladala prezemiociki ktore tam byla ulozyla "He's just turned to the box ... and automatically collects what he put before". Simple past shows the narrator's turming to the box and gathering of the things, his gathering things moment precedes this moment, and this is given by plusquamperfect instead of the simple past. Although we see past time twice in the plusquamperfect, the past meaning of the tense category is different from the previous past meaning.

The materials of the ancient Czech language confirm the action in advance meaning to the $\mathrm{A}_{2}$ of a certain time, in the form of plusquamperfect. For example: Kdyz biese otsel, tehdy Maia jide ... "Maria went after Gabriel has gone ..."
The Biese otsel form is one of the variants of plusquamperfect formed by the imperfect byti verb and participle -1. It is interesting to note that the authors, who say that the plusquamperfect is the result of progressive behavior (Shirokova A.D., Vasilyeva V.F., Edlichka A. The Czech language. M., 1990, 264), note that in advance action meaning is never grammatical and it gained strenght in the Czech plusquamperfect forms. Repetitive verbs in preterite are sometimes used to express in advance action meaning, for example: Temna postava se zastavila $b$ dveri pokoje, $v$ nemz bydlival nest'astny Jan Vaclav Piccolomini "A black figure stands in front of the room where the unfortunate Jan Vaslav Piccolomini lived" (Shirokova A.G. Basic meanings of multiple verbs in Czech language//The Linguistic Issues. 1965, № 2, 78). B.Koperski noted such cases and considereds the difference between nosil and nosival forms as tense difference, nosival shows the distant past meaning (Kopesky B. Grammar of Macedonian language. 1958, 101). However, we would like to agree with A.G.Shirokova, because she believes that in modern Czech language distant past mening belongings is not a grammatical meaning of repetitive verbs, as it usually results from influence of context or general situation (Shirokova A.G. Basic meanings of multiple verbs in Czech language//The Linguistic Issues. 1965, № 2, 83) .

Using of the past forms, which arise from repeated verbs with suffixes - blвa, $-и в a,-в a$ express the distant past action. However, it must be distinguished from "distant past tense" from the "previous past tense". Opposite to the binary-time relativity, which is typical for the previous tense (plusquamperfect), distant past tense refers to the processes that have occurred in the past, but not repetitive processes before the speech moment. It should be noted that many verbs in this group are used only in the past. In contrast, the Czech and Slovak languages there are present forms formed from the repetitive verbs. In this regard, Isaacenko I.V. notes that modern Russian forms like ухаживал relate to the distant past meaning in "favorable" contexts (Isaachenko A.V. Grammatical structure of Russian language in comparison with Slovak language. Morphology. Bratislava. 1960, 432). Thus, modern Russian language does not have morphological means for expressing distant past, previous past meanings.

There are no relative or absolute tense forms in the Bulgarian language, but the main feature of the Bulgarian temporal system is the verb action and result of verb action in grammatical layer. The grammatical forms transmit not the action, but its result attitudes to the moments [8; 7, 4757]. The attention is given to the result, not to the action expressed by the verb, that is, in this sense the verb form focuses on the result, not on the action occurrence time. In other words, the action with its result has the meaning. Result is shown in the perfect tense, f.e. Вадяло е, it means the street is wet. The result of the action is important, as the according to the result the action is restored. However, it can also mean that the perfect tense shows the action that has no material result in the speech moment. F.e. Мислил съм по този въпрос. In these cases, the perfect characterizes the present that is formed as a result of past actions. However, 
the speaker considers that the actual moment of action involves the speech moment, that is, the perfect determines the layering of the past to the present tense surface [9]. So in Bulgarian language it is possible to talk about resultative tenses.

They indicate not the action, but result attitude of $A_{1}$ and $\mathrm{A}_{2}$ moment. The present result is the perfect, the future result is the initial future. Plusquamperfect expresses the simultaneity of the result of the action with $\mathrm{A}_{2}$, the initial future in the past is the following action result from the $\mathrm{A}_{2}$. However, the attitude of the action and its consequence towards to the integrity moment does not overlap. If the result of action is $A_{1}$ and $A_{2}$, then the action itself occurs before the appropriate moment, that is, the action defined by the perfect occurred before the speech moment. The perfect is the resultative present.

The meaning of the initial future form reflects the resultativity, this form determines some action, which is relevant for any future moment, and the action ahead of that moment. For example: Война а ще свърии и дърветата ще иъфтят в мир. И ние с вас ще сме оздравели, ще бъдем напълно здравии "The war will end, and the trees will blossom peacefully. And we will be healthy with you. " It is, to some degree, the future in the past.

It recalled initial future perfect and the plusquamperfect towards to the binary tense. Thus, in the Bulgarian verb paradigm, apart from the category of time, taxis and the resulting grammatical categories are combined. Except for the aorist, each verb form enters into these three different opposites. The aorist, expressing action towards the speech moment, has no correlation in either taxis or resultative categories. At the same time, it should be noted that attempts to describe the verb form in the Bulgarian language in two categories - time and taxis are less successful, as it does not reflect all the relationship of the verb forms.

Comparing the Bulgarian language with the SerbianCroatian and Macedonian languages, it is necessary to involve the resultative category into the verb paradigm. It is true, the number of future tense in these languages is (2) less than in Bulgarian (6), and we can observe that these three languages are identical in tense and taxis. "Let's compare the actual meaning of perfect action and its perfect forms for the result of present tense in these languages: S.-C. ньеговы родительи су остарили "His parents are old", М .: Членом се има развиено от показни заменки "Member form is formed form the demonstrative pronouns".

In the Macedonian and Serbo-Croatian languages, plusquamperfect represents actuality of the action result of the past integrated moment. Мас. Гирнав низ решетката да си го видам езерото. Сонцето го беше позлатило "I tried to see the lake form the cage. From the sun it looks like gold. "- it was gold till appropriate past moment and remained gold in this past moment (Molochnaya, 54). Thus, it can be noted that it is difficult to understand the compatibility of the Serbian-Croatian and Macedonian perfect with other forms without consequence category - $A_{1}$ and $A_{2}$ - integrity moments, and the simultaneity, in advance, and laterity.

\section{DISCUSSION}

Thus, in addition to the past, there is preceding past or plusquamperfect in the grammatical system of the Czech language. Although the latter form is not used in the spoken language, it has reached the twentieth century. In modern Slovak language, the preceding past tense is presented as an independent grammatical form. E.Horak points out that the main meaning of the plusquamperfect is not the chronological preceding of one past time from another past, but it is the result of the action. However, plusquamperfect is facultative and is replaced by the past. There is no plusquamperfect in Russian language. However, the preceding meaning of the action can be expressed by special means. Thus, the verb form of the past with the было particle determines the past tense that transgresses the previous action. For example: Он хотел было встать, но передумал. Here we deal with the relative time. This meaning is close to the preceding past tense in an ancient Russian language.

Each specific language system has a specific morphological expression of these or other time intervals within a specific time plan. For example, in the ancient Slavic language there is a confrontation of the aorist forms of the past with the moment and the effect of the speech, and even in modern Russian the confrontation is carried out with non-morphological means. For example: in пришел and сразу сед за работу sentences the form сел shows unconditionality of the action towards speech moment. Bom я $и$ пришел - At this point it draws attention to the completeness of the action towards speech moment. However, grammatical tense expresses the meaning of the verb form and does not always coincide with the real. Thus, the word-form светят has a present tense meaning, but in Как ярко (сегодня) светят звезды sentence the reality does not coincide with the present. Gorshkova K.V. Kharburgayev G.A. Historical grammar of Russian language. M., Vishsaya shkola, 1981, 359 c. C.270).

The category of time is characterized by the flow of movement (or condition) in relation to the speech flow (absolute time) or to each moment of the last (relative) time. In the ancient Slavic language as well as in modern Russian, time is expressed in synthetic forms and with the help of analytical and auxiliary verbs (http://www.philol.msu.ru/ tezaurus/docs/1/articles/3/3/5 ).

In narrative regimes there is no relation of the sentence to the speech moment. In the Russian language, the narrative regime does not have any special grammatical form, however, this regime manifests itself in other ways, especially in the special meanings of verb forms. In narrative regime, the speech moment does not take place in the commentary of the sentence, giving its place to the present moment of the character or observer. In all cases, the past is equivalent to the present narrative. Situationally actualized speech is characteristic speech for the direct connection of the speaker and the listener. Situationally nonactualized speech assumes that there is no direct focus at the speech moment. 
The historical development of the Slavic language verb system shows that the category of tense is closely related to the aspect category.

The formation of future tense forms reflected in the Indo-European languages history no more exists in the Slavic languages, although such forms are not encountered in ancient Slavic monuments. In Proto-Slavic language the future tense was expressed in other ways.

In the ancient Slavic language the meaning of future action could be expressed by the present form of the verb. Present tense forms having future meaning could be both finished and unfinished, for example: Завтра я иду на pаботу. The meaning of the future time, which is not directly related to verb type differences, is defined by the context [10].

\section{CONCLUSION}

The formation of future tense forms reflected in the Indo-European languages history no more exists in the Slavic languages, although such forms are not encountered in ancient Slavic monuments. In Proto-Slavic language the future tense was expressed in other ways.
As a result, with the exception of Russian, all Slavic languages have a taxis category in addition to the morphological category. The Bulgarian, Serbian, and Macedonian languages are combined into three different morphological temporal categories in the verb tense system: tense, taxis, and result.

\section{References}

[1] Večerka, R. Charakteristiky současných slovanských jazyků. Jazyky v komparaci 2, Praha: Euroslavica. 2009.

[2] Volodin A.P., Khrakovskij V.S. Парадигма русского императива Scientific notes University of Tartu. 1985, vol. 719.

[3] Rezanova Z.L. Subjective Images of Time in Modern Slavic Languages: Diminutive Models. Siberian $\begin{array}{lll}\text { physiological Journal. } & \text { 2017, }\end{array}$ DOI: $10.17223 / 18137083 / 60 / 14$.

[4] Lamprecht A. Praslovanština. Brno. 1987.

[5] Karlík, P.; Nekula, M.; Rusínová, Z. Příruční mluvnice češtiny. Praha: Lidové noviny, 2012.

[6] Kutsarev Iv. Essay on functional-semantic grammar in Bulgarian. Plovdiv. 1985

[7] Kutsarev Iv. Problems of Bulgarian morphology. Plovdiv. 1993.

[8] Gerdzhikov G. Bulgarian verbs are the days of the Kato system. Sofia. 1976.

[9] Penchev J. Time, taxis, syntax. Bulgarian.1985, 6, pp. 34-45.

[10] URL: http://www.philol.msu.ru/ tezaurus/docs/1/articles/3/3/5. 